\title{
FDI Location Decision: Evidence from Firms Investing in China
}

\author{
Omar Belkhodja $^{1}$ \\ ${ }^{1}$ Management Department, School of Business Administration, American University of Sharjah, United Arab \\ Emirates \\ Correspondence: Omar Belkhodja, Management Department, School of Business Administration, American \\ University of Sharjah, Sharjah, United Arab Emirates. E-mail: obelkhodja@aus.edu
}

Received: March 30, 2016

doi:10.5539/ijbm.v11n6p47
Accepted: April 27, 2016

Online Published: May 22, 2016

\begin{abstract}
By relying on an extensive set of firm data for foreign affiliates in China, the paper investigates the determinants of FDI location choice for multinational firm subsidiaries located in different special economic and investment zones. Using a logit estimation, the results suggest that various factors explain the location choice of FDI in China, and vary according to the country of origin and the sector of activity. Overall, the results show that the protection of intellectual rights, the agglomeration economies, the investments in education and the GDP of the region affect the location choice of FDI. Implications can be drawn for policy-makers to divert FDI from coastal to inland regions. Finally, the last part of the paper derives, from the obtained results, implications for future research and theory building.
\end{abstract}

Keywords: FDI, location choice, policy, China, foreign investment

\section{Introduction}

Research on foreign direct investment (FDI) has attracted much attention in recent years from scholars from multiple disciplines (Girma et al., 2005; Bitzenis, 2006; Das \& Pant, 2006; Xing \& Wan, 2006; Kang \& Lee, 2007). Many factors have been identified as determinants of FDI. The list of determinants include relative wages and income convergence (Choi, 2004), GDP of the host country (Shapiro \& Globerman, 2003), labor market (Giulietti et al., 2004; Janicki \& Wunnava, 2004; Kang \& Lee, 2007), and intellectual property rights protection (Wu, 2000; Javorcik, 2004). China, the most populous country in the world, has experienced a dramatic increase in FDI inflows since the adoption of the "open-door" policy in late 1978 by Chairman Deng Xiaoping. The creation of a wide range of investment zones and special economic zones offering different types of incentives made foreign investments soar to unreached levels.

The study of the determinants of location choice has increased in popularity these recent years and a growing number of studies has been undertaken to empirically identify, test, and analyze the influential factors on the location choice by foreign investors in the Chinese context. While earlier studies on FDI in China focused on its volume and sectorial characteristics (e.g. Zhang, 1994; Schroath et al., 1993; Cheng \& Stough, 2006), only few of them took into account the impact of the country of origin on foreign investors' location choice. While Schroath et al. (1993) argued that cultural and geographical factors play an important role in the spatial concentration of FDI, Qu and Green (1997) suggested that the country of origin determines the location choice and demonstrated that FDI from USA, Japan, and European countries is interested in city sizes, consumption levels and infrastructure in its location decisions (Cheng \& Stough, 2006). He (2003) concluded, in the same vein, that Japanese investors have special location preferences compared to other investors while FDI from Hong Kong is generally sensitive to geographical and cultural proximity. Moreover, agglomeration economies has also been identified as a significant factor in the location decisions of FDI in China as FDI usually follows the patterns of prior FDI stock (Broadman \& Sun., 1997; Wei et al., 1999).

The provinces in China are classified into three regions: Eastern, Central and Western. The distribution of FDI among China's regions remains asymmetrical showing a marked interest of investors for the accessible Eastern region, especially the traditional industrial centers among the fourteen coastal cities and the Special Economic Zones (SEZs) in Shenzhen, Zhuhai, Shantou, Xiamen, and Hainan. The policies developed by the Chinese government in the late 1970s and in the 1980s favored the Eastern region over the Central and Western regions 
in China and created enormous regional development differences between coastal and inland cities even though statistics showed that the number of foreign enterprises in inland provinces increased by tenfold and investment values increased by more than twenty times in the first half of the 1990s (Luo \& O'Connor, 1995). Moreover, the sectorial distribution of FDI shows that agriculture has received very little FDI inflows. On the other hand, the service sector, particularly real estate, has attracted huge amounts of investments in the 1980s. However, since 1987, policies were developed to discourage investments in the service sector in favor of the industrial sector (Wu, 1991; Xu, 1992). Overall, FDI in China is usually directed to secondary industries like utilities, manufacturing, and property development, with the primary sector attracting about one fourth of the total FDI (Kang \& Lee, 2007).

Two gaps have been identified in the literature: 1- Very few studies analyzed the attractiveness of investment zones and economic zones from an empirical standpoint. In this paper, we argue that the probability that foreign affiliates choose an investment zone or a more specialized type of economic zone is determined by a set of location choice variables. The location choice must provide foreign investors a competitive advantage as it must be more profitable to invest in that location than in others (Coughlin et al., 1991). 2- Studies focused either on a particular set of countries of origin or on a particular set of determinants of location choice. We propose to study the influence of the country of origin on the foreign affiliates FDI and their decision to stay in the same investment or economic zone. An extensive list of determinants will be tested on the retained observations. Analyzing the determinants of location choice in China can help us understand the impacts of Chinese economic policies and design specific regional and local policies to attract FDI from a specific country of origin. The objectives of the article are twofold: 1- to study the determinants of FDI location choice (investment zone or economic zone) of foreign affiliates in China including the effects of the country of origin; and 2- to draw recommendations for policy-makers to boost FDI inflows in inland regions in China. The paper is organized as follows: In a first part, it introduces the different economic zones in China and analyzes, using the literature in international business, the different determinants of location choice in China. The second part deals with the empirical aspects of the research. It introduces the methodology and data used, the measures of the dependent variables, the descriptive statistics and finally the results of the logit models. The third and last part of the paper is dedicated to the analysis of the results and to the discussion of their implications. The limitations of the study and suggestions for future research are presented in the last section of the article.

\section{China's Economic Zones}

China has attracted large amounts of FDI these recent years after the initiation of economic reforms and the adoption of the open-door policy instituted in the late 1970s. The trend of foreign investments has increased after the accession of China to the World Trade Organization in 2001. This has directed increasing attention from researchers over the years (Beamish, 1993; Zhao \& Zhu, 1998) to study the location choice of FDI in China. However, it is noted that disparities still exist between coastal and inland provinces in their capacity to attract and host FDI (Fujita \& Hu, 2001; Cheng \& Kwan, 2000; Sun et al., 2002). These disparities can be explained by the cultural and geographical proximity between pacific territories and China coastal regions. However, proximity is not the sole factor that causes FDI to flow to coastal regions. In fact, China, through its economic policies, did quite exclusively encourage investments in coastal regions. In the original Act of Joint Venture Enterprises in 1979, foreign investment was limited to four Special Economic Zones (SEZs): Shantou, Shenzhen, Xiamen and Zhuhai. The fifth zone, Hainan, was added in 1988 (Zhou et al., 2002). A series of incentives were provided to encourage FDI including a two-year tax holiday that was granted to foreign subsidiaries in the first two-years of profitable operations while the third to fifth years of profitability were taxed at $50 \%$ of normal rates. Undeniably, the creation of these special economic zones boosted the flow of FDI but difficulties still existed as the infrastructure and workers' productivity did not meet international standards while bureaucracy increased the transaction costs faced by foreign investors. Later, the scope of these economic zones was broadened to become open economic cities known as Open Coastal Cities (OCCs) (Zhou et al., 2002). The Open Coastal Cities list includes Dalian, Qinhuangdao, Tianjin, Yantai, Qingdao, Lianyungang, Nantong, Shanghai, Ningbo, Wenzhou, Fuzhou, Guangzhou, Zhanjiang, and Beihai. Although several of these Open Coastal Cities possess better infrastructures than SEZs, they do not, in general, enjoy the same tax incentives and status. Foreign enterprises located in these economic zones generally pay national profit taxes at rates of $24 \%$ to $30 \%$ while those in SEZs pay as low as $15 \%$ (e.g. Zhou et al., 2002). Similar differences existed in other areas such as exemptions and reductions of profit taxes, import duties, and land use fees (Cheng \& Kwan, 2000).

While these economic zones and open cities are in their majority located on the coasts, the Chinese government introduced the New and High Technology Industrial Development Zones (NTZ) along with the creation of another type of zone labeled Economic and/or Technology Development Zones (ETDZs) to encourage the 
creation of special zones. Another type of economic zone labeled Free Trade Zones (FTZ) or Tax Protection Zones whose focus was to foster international commerce by removing or reducing import duties and import quotas and changing the tax structure to foster the development of local and foreign businesses was also created. ETDZs are quite different from SEZs and OCCs as they only cover a small area within cities where investors benefit from preferential policies. Moreover, administrators of ETDZ have more freedom to issue preferential policies than those of ETDZs. The focus of ETDZ is also somewhat different as they mainly target the enhancement of the competitiveness of specific industries by emphasizing the development of productive capabilities and technology research while prioritizing infrastructure development and the provision of energy and communications (Jia, 1994). Meanwhile, the Special Economic Zones (SEZs) have for objective to encourage export-oriented investments. According to Beamish and Wang (1989) and Hayter and Han (1997), SEZs and OCCs were the most prominent in FDI attraction during the 1980s. Beamish and Wang (1989) reported that these economic regions attracted 65.6 percent of the total amount of FDI during that period. However, the share of FDI in these areas, particularly in SEZs, declined since the 1990s (Goddard, 1997; Hayter \& Han, 1997). The creation of other types of economic zones and the fierce competition in terms of incentives has led the share of FDI invested in SEZs to sharply decline from its $90 \%$ pick in value registered in the late 1980s (e.g. Goddard, 1997). At the same moment, investors had few viable alternatives other than the 19 open cities (5 SEZs and 14 OCCs). This decrease in investments in SEZs can also be explained by the policies adopted by the Chinese government to encourage investments in inland zones and cities (e.g. Goddard, 1997; Hayter \& Han, 1997).

\section{The Determinants of Location Choice}

Empirical studies on the determinants of location of FDI in China used both aggregate and disaggregate methodologies and their applicable FDI data sets. In the aggregate approach, ordinary least square (OLS) method is generally used and assumes that FDI stocks are normally distributed across cities and provinces and that the city or the province is able to accumulate any specific volume of FDI in any year and over years (Cheng \& Stough, 2006). In the disaggregate approach, each individual firm or observation is examined against observable location characteristics. Aggregate studies have shown that factors such as transportation and communication infrastructure, market size, and policy incentives are important determinants at the city level (Gong, 1995; Zhao \& Zhu, 2000, Rasciute et al., 2014). At the provincial level, similar findings including positive effects of infrastructure, market size and policies (Fu, 2000; Fung et al., 2002; Sun et al., 2002) have been identified as determinants of FDI. In the same regard, agglomeration economies have been identified as a significant factor to attract FDI at both city and provincial levels. Studies have also shown that location decisions may vary over time In China, market size and transportation conditions were found to play an increasingly important role in attracting FDI from 1987 to 1998 (Zhang, 2001), while as noted previously, the influence of policies has decreased over time (Hong, 2007). While there is a consensus from different empirical studies on the variables that influence location choices of FDI such as labor, cost, skilled labor, agglomeration effects and government policies, the capacity of a city or province to compete effectively through the creation of a sustainable competitive advantage and to drain significant flows of FDI depends on the linkages between education, government and industry that encourage in the long run the development of new activities in the region, leading to innovation and further investments (Porter \& Stern, 2001, Rasciute et al., 2014). Bhagwati and Srinivasan (1983), and Sun et al. (2002) found, in this regard, a correlation between investments in scientific research and FDI flows. The effects of patent protection on foreign investment (FDI) remain, however, ambiguous.

The effects of labor cost on the location choice of FDI in China are not clear. High labor costs has been found to be a deterrent to FDI in some studies (Belderbos \& Carree, 2002; Cheng \& Kwan, 2000; Fung et al., 2002; Wei \& Liu, 2001; Li et al., 2008). However, Baghwati and Srinivasan (1983), Coughlin et al. (1991) and Wang and Swain (1995) in their respective studies found a correlation between wage and labor cost. Broadman and Sun (1997), Chen (1996), and Head and Ries (1996) found a statistically insignificant correlation between the location of FDI and labor cost. Zhao and Zhu (2000), who argued that wage levels need to be linked to productivity levels, found a positive correlation between high labor costs and FDI attraction. High wages can be interpreted as a sign of high labor cost or of skilled and quality labor force. The argument introduced by Zhao and Zhu (2000) has been echoed by Cassidy (2002) and Wei et al. (1999) who discussed the notion of effective wages while using productivity as a control variable. Their results showed that higher effective wages foster the level of FDI as superior labor quality is usually associated with high effective wages and investors would consider investing in areas with large pools of high-quality labor forces (He, 2001).

Agglomeration, measured by the infrastructure quality, refers to the concentration of economic activities that lead to positive externalities and economies of scale ( $\mathrm{Na} \&$ Lightfoot, 2006). A number of authors including 
Coughlin et al. (1991), Wheeler and Moody (1992) and Braunerhjelm and Svensson (1996) found that the degree of agglomeration was positively correlated with FDI. In a like vein, intellectual property rights protection was identified as a major determinant of FDI location choice in Wu (2000) and Javorcik (2004) studies. Moreover, past research has shown that market size has a positive impact on FDI inflows which tend to prove that the larger the market size of a particular region, the more FDI the region should attract (Blomstrom \& Lipsey, 1991; Na \& Lightfoot, 2006; Lee et al., 2008). Finally, investments in education as well as a high enrollment in high education tend to offset the disadvantages of a particular location as they help increase the pool of skilled workers and attract FDI.

Other determinants will be tested in this study including the localization (Metropolis or not), the number of branches, and the country of origin. We will test the probability that foreign investors invest in economic zones and cities that provide fewer incentives than the following investment zones (SEZs, OCCs and ETDZ).

\section{Methodology and Data}

The sample used in this study consisted of 1218 foreign firms present in China from 2010 to 2012. Data was pulled from The China Foreign Enterprise Directory published by China Economic Review in its 2011, 2012, and 2013 editions. The directory provides information about the industry, the location, the country of origin, and the management of foreign companies. The sectors of activity include agriculture, manufacturing, airlines, banking, finance and insurance, healthcare and pharmaceuticals, real estate \& construction, technology and communication, and transportation and warehousing. Our interest was to study FDI in manufacturing sector, more specifically in the following subsectors: aeronautics and maritime, automotive, consumer goods, industrial products, materials, paper, packaging and printing, textile, and general manufacturing. A discrete-choice model, namely, binary logit model was used with disaggregate observations to study the determinants of FDI location choice in China. Discrete choice models empower researchers to reveal each individual choice maker's preferences, some of which may be lost in the aggregate methodologies (such as OLS) (Cheng \& Stough, 2006).

\subsection{Measures}

The two discrete-choice models used two dependent variables representing the different types of economic zones that host FDI. In the first model, the dependent variable LOCATION was coded " 0 " if foreign investments were made in SEZs, OCCs or ETDZs and was coded "1" if these investments were made in other types of economic zones and cities. Appendix 1 delineates the definitions of independent variables used in this study.

\subsubsection{Descriptive Statistics}

Overall, $43.8 \%$ of the firms included in the data set are from Europe, while $36.9 \%$ have headquarters in the USA. The percentage reaches $9.4 \%$ for Japanese firms. The rest is divided between FDI inflows from firms located in Hong Kong, in South Asia, and in other parts of the world. The percentages are respectively of $56.9 \%$ for investments in the general manufacturing subsector, $14.9 \%$ in the automotive subsector, $7.3 \%$ in the industrial products subsector, $7.1 \%$ in the paper industry, and a cumulated percentage of $13.8 \%$ for the other sectors of activity. Overall, $35.2 \%$ of these firms have one branch in China, whereas $64.8 \%$ of the firms included in the data set have multiple branches. The percentage reached $85.4 \%$ for firms located in cities with a population of more than 3 million people, while $7.2 \%$ of the investments were in cities with less than 1 million in population. The data shows that $70.7 \%$ of the investments are made in regions with high GDP, $25.5 \%$ in regions with an average GDP, and 3.8\% in regions with a low GDP (Refer to Appendix 1).

\subsection{Analytical Models and Results}

In this study, we assume that foreign investors took the decision to invest and stay in a specific location based on a set of factors that impact and determine their evaluation of the investment context. Their evaluation of the context surrounding the investment decision is based, among other determinants, on the assessment of the impact of the agglomeration effects, the GDP of the region, the wage level, the investments in education, and the protection of intellectual rights. These predictors of location choice determine foreign investors' willingness to invest in SEZs, OCCs and ETDZs or in other economic zones and cities, and their decision to retain their investment in that specific location.

\subsection{The Determinants of Location Choice in Economic Zones and Cities}

The decision to invest in newly created economic zones and cities other than SEZs, OCCs and ETDZs is measured using a binary variable (LOCATION) capturing the fact that foreign investments have been made in other types of economic zones and cities versus in SEZs, OCCs and ETDZs. The data obtained was coded " 0 " if investments were made in SEZs, OCCs and ETDZs and "1" otherwise. 
Results of the regressions corresponding to the location choice of FDI in China are summarized in table 1 . The equations have good predictive power, with $65.3 \%$ of correct predictions in the comprehensive model, $92.1 \%$ for the "Europe" model, $98.5 \%$ for the "USA" model, and $86.7 \%$ for the "Japan and South Asia" model. Therefore, the comprehensive model correctly classified $65.3 \%$ of the observations into foreign investments in SEZs, OCCs and ETDZs or otherwise. Other models correctly classified respectively $92.1 \%, 98.5 \%$, and $86.7 \%$ of the firms into those located in SEZs, OCCs or ETDZs and those located in other economic zones and cities. The value of the Nagelkerke $\mathrm{R}^{2}$ (Pseudo $\mathrm{R}^{2}$ ) is .842 for the comprehensive model, .849 for the "Europe" model, .918 for the "USA" model, and .777 for the "Japan and South Asia" model. These values can be considered as reasonable for qualitative dependent variable models. Furthermore, the computed value of the likelihood ratio (i.e., 972.2 for the comprehensive model) is much larger than the respective critical values of the Chi-squared statistic with 11 degrees of freedom at the 1 percent level for the comprehensive model and with 10 degrees of freedom at the 1 percent level for each of the other models estimated. This suggests that the null hypothesis, that the parameter coefficients (except the intercept) are all zero, is strongly rejected for all the models. Consequently, the models are significant at the 1 percent level.

Overall, the likelihood to invest in other economic zones and cities increases as the intellectual property rights protection strengthens, as the infrastructure improves, as the enrolment in high education increases, as the funds allocated to education increase and as the land price increases. However, the likelihood to invest in other economic zones and cities will tend to decrease if the GDP of the region increases and in sectors such as general manufacturing, paper, and textile. Let us turn our attention to each of the country of origin specific models. The likelihood of a firm to invest in other economic zones and cities will increase as intellectual property rights protection improves except for Japanese and South Asian firms. An improvement in the infrastructure will positively affect the perception that foreign investors have of other economic zones and cities (other than SEZs, OCCs and ETDZs), except for American investors. In the same vein, an appreciation of the amount invested in education and an increase in the enrolment rates in high education have a positive impact on all foreign investors' perception except on European, Japanese and South Asian investors. An increase in land prices will produce the same positive effect except on European investors. The likelihood to invest in other economic zones and cities is low in the textile, paper and, general manufacturing subsectors. Finally, all foreign investors become more reluctant to invest in the different economic zones as the GDP of the region increases except for investments originating from Japan and South Asia.

Let us focus on $\operatorname{Exp}(\beta)$ corresponding to the parameters of some significant explanatory variables in the comprehensive model. Investors are more likely to invest in the other economic zones and cities when intellectual property rights protection increases and infrastructure improves. Investors from all countries of origin are more willing to invest when education budgets and enrolment in high education increase. They are also more likely to invest in these economic zones when land prices increase. Finally, they are less likely to invest when the regional GDP appreciates. Predicting the behaviour of European investors, the "Europe" model shows that the probability of investing in other economic zones and cities increases when intellectual property rights are protected, when the city is a metropolis, and when infrastructure improves. Investors are less likely to invest when the regional GDP increases. U.S. investors' likelihood to invest increases after an improvement of the protection of intellectual rights, an improvement in the enrolment in high education and an increase in educational budget. Compared to the other foreign investors, FDI from Japan and South Asia increases when local governments invest in the infrastructure.

Table 1. Estimated logit models of factors affecting location choice (dependent variable: SZE, OCC or ETDZ versus otherwise)

\begin{tabular}{|c|c|c|c|c|c|c|c|c|}
\hline \multirow[b]{2}{*}{ Independent variables } & \multicolumn{2}{|c|}{ Comprehensive } & \multicolumn{2}{|l|}{ Europe } & \multicolumn{2}{|l|}{ USA } & \multicolumn{2}{|c|}{ Japan and South Asia } \\
\hline & Coeff. $\beta^{a}$ & $\begin{array}{l}\text { Exp. } \\
(\beta)\end{array}$ & $\begin{array}{l}\text { Coefficients } \\
\beta^{\mathrm{a}}\end{array}$ & $\begin{array}{l}\text { Exp. } \\
(\beta)\end{array}$ & $\begin{array}{l}\text { Coefficients } \\
\beta^{\mathrm{a}}\end{array}$ & $\begin{array}{l}\text { Exp. } \\
(\beta)\end{array}$ & $\begin{array}{l}\text { Coefficients } \\
\beta^{\mathrm{a}}\end{array}$ & $\begin{array}{l}\text { Exp. } \\
(\beta)\end{array}$ \\
\hline INTERCEPT & -10.2 & 0.000 & -9.175 & 0.000 & -16.592 & 0.000 & -4.029 & 0.018 \\
\hline Country of Origin & 0.093 & 1.097 & & & & & & \\
\hline Activity sector & $-0.617^{* * *}$ & 0.539 & $-0.591 * * *$ & 0.554 & $-1.242 * * *$ & 0.289 & $-0.917 * * *$ & 0.400 \\
\hline Multiple branches & -0.398 & 0.672 & -0.485 & 0.616 & -1.326 & 0.265 & -0.624 & 0.536 \\
\hline Wage level & -0.403 & 0.668 & -0.358 & 0.699 & -0.258 & 0.773 & -1.211 & 0.298 \\
\hline Land price & $0.654 * * *$ & 1.924 & 0.510 & 0.144 & $0.882 *$ & 2.417 & $0.930 *$ & 2.535 \\
\hline Educational funds & $0.783 * * *$ & 2.187 & 0.517 & 1.676 & $3.464 * * *$ & 31.94 & 0.069 & 1.071 \\
\hline
\end{tabular}




\begin{tabular}{|c|c|c|c|c|c|c|c|c|}
\hline High education enrolment & $0.728 * * *$ & 2.072 & 0.444 & 1.559 & $3.544 * * *$ & 34.609 & 0.270 & 1.309 \\
\hline Gross regional Product & $-2.622 * * *$ & 0.073 & $-2.837 * * *$ & 0.059 & $-9.007 * * *$ & 0.000 & 0.09 & 1.094 \\
\hline Infrastructure/Freight & $6.207 * * *$ & 496.06 & $5.968 * * *$ & 390.866 & 11.855 & 140.38 & $5.957 * * *$ & 386.36 \\
\hline $\begin{array}{l}\text { localization } \\
\text { (metropolitan/not) }\end{array}$ & 0.532 & 1.702 & $1.164 * *$ & 3.202 & -0.739 & 0.478 & -0.373 & 0.688 \\
\hline \multirow[t]{2}{*}{ Intellectual Property } & $3.136 * * *$ & 23.015 & $2.856^{* * *}$ & 17.393 & $9.043 * * *$ & 846.65 & 0.985 & 2.679 \\
\hline & 1218 & & 445 & & 391 & & 150 & \\
\hline Chi-square (df) & $972.28(11)$ & & $442.13(10)$ & & $396.24(10)$ & & $120.866(10)$ & \\
\hline Nagelkerke $\mathrm{R}^{2}$ (pseudo- $\mathrm{R}^{2}$ ) & 0.842 & & 0.849 & & 0.918 & & 0.777 & \\
\hline $\begin{array}{l}\text { Percentage of correct } \\
\text { predictions }\end{array}$ & $65.3 \%$ & & $92.1 \%$ & & $98.5 \%$ & & $86.7 \%$ & \\
\hline
\end{tabular}

a $*, * *$ and $* * *$ indicate that variable is significant at $10 \%, 5 \%$ and $1 \%$, respectively.

\section{Discussion and Implications}

Two research questions are addressed in this paper: 1- What are the determinants of FDI location choice of foreign affiliates in China? 2- What recommendations can be drawn from the results for policy-makers to boost FDI inflows in inland regions in China?

In a context where the number of empirical studies on FDI location choice in China is still low, this paper contributes to the advancement of knowledge by providing new evidence on the determinants of location choice of foreign investors. The study shows that factors such as investments in education or infrastructure and protection of intellectual rights increase the probability that the economic zones and the cities that do not possess a status of special economic zone attract FDI inflows. The predictors of location choice can vary according to the country of origin or region.

The results show that the protection of intellectual rights can positively affect the perception that foreign investors have of economic zones and cities that do not possess the preferential status of SEZs, OCCs and ETDZs. This important determinant of location choice makes potential investors from Europe and USA increase their investments in these economic zones and cities instead of investing in the more established investment zones, usually located in coastal cities. The results indicate that Japanese and South Asian investors are not impacted by improvements of intellectual rights protection. This result can be explained by the fact that cultural and geographic proximity makes Asian investors sensitive to a different set of contextual factors whereas the huge cultural and geographic distance between Europe and the U.S. on one hand, and China on the other hand, and their poor knowledge of the Chinese culture and business context increase investors' risk aversion. Overall, the investment context in coastal locations characterized by a high potential of agglomeration economies continues to attract foreign investors. The infrastructure of the preferred location has a positive impact on investors' behaviour except for investors from USA who prefer to invest in more established economic zones. The investments in the infrastructure can be used by Chinese policy-makers as a lever to attract FDI to Central and Western regions. However, the gross regional product (GRP) does not seem to have a positive impact on foreign investors' behaviour, as an increase in the GRP lowers the probability that investors pick the newly developed investment zones as a location for their investments in China. A higher GRP can be interpreted by investors as an indicator of a high standard of living and of high costs which impedes foreign investments. For instance, Japanese and South Asian investors remain not sensitive to an increase of the GRP. An increase in enrolment rates in high education and in the amount of money invested in education offset some of the disadvantages of economic zones and increases their attractiveness against SEZs, OCCs and ETDZs. European investors as well as Japanese and Asians believe that the availability of a more educated pool of job candidates does not improve investment prospects.

Overall, the results highlight the sectorial segregation of foreign investors' behaviours. They show, in this regard, that investments in some subsectors can easily be moved to other economic zones and cities whereas agglomeration effects determine investors' behaviour in other subsectors. It is the case in manufacturing, paper, packaging and printing, and textiles. The paper stresses out that behaviours are grounded in sectorial activities and shows that the extent to which agglomeration impacts FDI location choice differs from one industry to another.

An important contribution of this study is to demonstrate that determinants of location choice of FDI can be used by Chinese policy-makers as a lever to increase FDI inflows in Central and Western parts of China. The unbalanced growth in FDI inflows between the Eastern- coastal- regions and the rest of the country pleads in 
favour of a readjustment of developmental forces across regions and of a better distribution of resources between inland and coastal regions. Enforcing intellectual property rights protection can be used a lever to divert investments to inland cities. The study shows that agglomeration is a significant determinant of FDI location choice in China. Investments in education, seen by investors as a promise of the availability of a large pool of high skilled workers, can foster the probability that inland cities and regions get an increasing share of the FDI in China. Policy-makers should be aware of the specificities of each sector of activity and develop policies tailored to the meet the specific needs of different groups of foreign investors. Our study confirms that agglomeration economies is a significant factor in the location decisions of FDI in China and that, as stated by Broadman and Sun (1997) and Wei et al. (1999), investors tend to follow the patterns of prior FDI stock. The study points towards the tendency of Japanese and South Asian investors to rely on cultural and geographical proximity in FDI-related decisions with confirms the results highlighted by He (2003). Conversely, European and American investors are more willing to revise their investment choices based on economic incentives or advantages. Our results point in the same direction than the study conducted by Qu and Green (1997) who found that the country or region of origin is a major determinant of foreign investors' behaviour. However, our study found an insignificant correlation between the location of FDI and labour cost. The same result was highlighted by Broadman and Sun (1997), Chen (1996) and, Head and Ries (1996) in their respective studies.

The study contributes to add new evidence to the debate regarding the location choice of FDI in general and in China in particular. The study confirms the importance of agglomeration economies, of intellectual property rights protection, and the role that investments in education play in attracting foreign investors. It also confirms the effect of the country of origin on FDI location choice and, the sectorial differences and their impacts on foreign investors' behaviour.

The main limitation of our study is that it considers a specific set of determinants of location choice. Due to data limitation, we were unable to take into account the effects of FDI policies, tax incentives, and cumulative FDI. A larger pool of data regrouping observations from different industries should be used in future studies. Different methodologies should also be combined to identify, with more accuracy, what determines the behaviour of foreign investors. The use of different theories grounded in different fields of study can enrich the explanation of FDI location choice in China. Finally, more work is needed to identify, with more accuracy, the factors affecting the location choice of FDI in general and in China in particular.

\section{References}

Beamish, P. W. (1993). The characteristics of joint ventures in the People's Republic of China. Journal of International Marketing, 1(2), 29-48.

Beamish, P., \& Wang, H. Y. (1989). Investing in China via joint ventures. Management International Review, 29, 57-64.

Belderbos, R., \& Carree, M. (2002). The location of Japanese investments in China: Agglomeration effects, Keiretsu, and firm heterogeneity. Journal of the Japanese and International Economies, 16, 194-211. http://dx.doi.org/10.1006/jjie.2001.0491

Bhagwati, J. N., \& Srinivasan, T. N. (1983). Lectures in International Trade. MIT Press.

Bitzenis, A. (2006). Decisive FDI barriers that affect multinationals' business in a transition country. Global Business Economics Review, 8, 87-118. http://dx.doi.org/10.1504/GBER.2006.008778

Blomstrom, M., \& Lipsey, R. E. (1991). Firm size and foreign operations of multinationals. Scandinavian Journal of Economics, 93(1), 101-107. http://dx.doi.org/10.2307/3440424

Braunerhjelm, P., \& Svensson, R. (1996). Host country characteristics and agglomeration in foreign direct investment. Applied Economics, 28(7), 833-840. http://dx.doi.org/10.1080/000368496328272

Broadman, H. G., \& Sun, X. (1997). The distribution of foreign direct investment in China. World Economics, 20(3), 339-361. http://dx.doi.org/10.1111/1467-9701.00073

Cassidy, J. F. (2002). Japanese direct investment in China: Locational determinants and characteristics. New York: Routledge.

Chen, C. (1996). Regional determinants of foreign direct investment in mainland China. Journal of Economic Studies, 23(2), 18-30. http://dx.doi.org/10.1108/01443589610109649

Cheng, L. K., \& Kwan, Y. K. (2000). What are the determinants of the location of foreign direct investment? The Chinese experience. Journal of International Economics, 51. http://dx.doi.org/10.1016/S0022-1996(99)00032-X 
Cheng, S., \& Stough, R. R. (2006). Location decisions of Japanese new manufacturing plants in China: A discreet-choice analysis. Annals of Regional Science, 40, 369-387. http://dx.doi.org/10.1007/s00168-005-0052-4

Choi, C. (2004). Foreign direct investment and income convergence. Applied Economics, 36, 1045-1049. http://dx.doi.org/10.1080/0003684042000246759

Coughlin, C. C., Terza, J. V., \& Arromdee, V. (1991). State characteristics and the location of foreign direct investment within the United States. Review of Economics and Statistics, 73(4), 675-83. http://dx.doi.org/10.2307/2109406

Das, S. K., \& Pant, M. (2006). Incentives for attracting FDI in South Asia. International Studies, 43, 1-32. http://dx.doi.org/10.1177/002088170504300101

$\mathrm{Fu}$, J. (2000). Institutions and investments: Foreign direct investment in China during an era of reforms. Ann Arbor: University of Michigan Press.

Fujita, M., \& Hu, D. (2001). Regional disparity in China 1985-1994: The effects of globalization and economic liberalization. Annals of Regional Science, 35(3). http://dx.doi.org/10.1007/s001680000020

Fung, K. C., lizaka, H., \& Parker, S. (2002). Determinants of U.S. and Japanese foreign direct investment in China. Journal of Comparative Economics, 30(3), 567-578. http://dx.doi.org/10.1006/jcec.2002.1788

Girma, S., Kneller, T., \& Pisu, M. (2005). Exports versus FDI: An empirical test. Review of World Economics, 141, 193-218. http://dx.doi.org/10.1007/s10290-005-0025-9

Giulietti, M., Mc Corriston, S., \& Osborne, S. (2004). Foreign direct investment in the UK: Evidence from a disaggregated panel of the UK food sector. Applied Economics, 36, 653-663. http://dx.doi.org/10.1080/0003684042000222043

Goddard, C. (1997). China Market Atlas. Hong Kong: The Economist Intelligent Unit.

Gong, H. (1995). Spatial patterns of foreign investment in China's cities, 1980-1989. Urban Geography, 16(3), 198-209. http://dx.doi.org/10.2747/0272-3638.16.3.198

Hayter, R., \& Han, S. S. (1997). Reflections on China's open policy towards foreign direct investment. Regional Studies, 32(1), 1-16. http://dx.doi.org/10.1080/00343409850123585

He, C. (2001). Locational choices and export decisions of foreign manufacturing enterprises in China. Unpublished Doctoral Dissertation. Arizona State University.

He, C. (2003). Location of foreign manufacturing in China: Agglomeration economies and country of-origin effects. Papers of Regional Science, 82(3), 351-372. http://dx.doi.org/10.1007/s10110-003-0168-9

Head, K., \& Ries, J. (1996). Inter-city competition for foreign investment: Static and dynamic effects of China's incentive areas. Journal of Urban Economics, 40(1), 38-60. http://dx.doi.org/10.1006/juec.1996.0022

Hong, J. (2007). Firm-specific effects on location decisions of foreign direct investment in China's logistics industry. Regional Studies, 41(5), 673-683. http://dx.doi.org/10.1080/00343400601120304

Janicki, H. P., \& Wunnava, P. V. (2004). Determinants of foreign direct investment: Empirical evidence from EU accession candidates. Applied Economics, 36, 505-509. http://dx.doi.org/10.1080/00036840410001682214

Javorcik, B. S. (2004). The composition of foreign direct investment and protection of intellectual property rights: Evidence from transition economies. European Economics Review, 48, 39-62. http://dx.doi.org/10.1016/S0014-2921(02)00257-X

Jia, W. (1994). Chinese foreign investment laws and policies: Evolution and Transformation. Wesport, CT: Quorum Books.

Li, X., Hou, K., \& Lu, M. W. (2008). An Empirical Study of Foreign Direct Investment Location in Eastern China. The Chinese Economy, 41(6), 75-98. http://dx.doi.org/10.2753/CES1097-1475410604

Luo, Y., \& O'Connor, N. (1998). Structural changes to foreign direct investment in China. Journal of Applied Management Studies, 7(1), 95-109.

Na, Lv., \& Lightfoot, W. S. (2006). Determinants of foreign direct investment at the regional level in China. Journal of Technology Management in China, 1(3), 262-278. http://dx.doi.org/10.1108/17468770610704930

Porter, M. E., \& Stern, S. (2001). Innovation: Location matters. MIT Sloan Management Review, 3, 28-36. 
Qu, T., \& Green, M. B. (1997). Chinese foreign direct investment: A subnational perspective on location. Ashgate. Brookfield.

Rasciute, S., Pentecost, E., \& Ferrett, B. (2014). Firm heterogeneity in modelling foreign direct investment $\begin{array}{llll}\text { location decisions. } & \text { Applied }\end{array}$ http://dx.doi.org/10.1080/00036846.2013.872760

Schroath, F. W., Hu, M., \& Chen, H. (1993). Country-of-origin effects of foreign investments in the People's Republic of China. Journal of International Business Studies, 24, 277-290. http://dx.doi.org/10.1057/palgrave.jibs. 8490233

Sun, Q., Tong, W., \& Yu, Q. (2002). Determinants of foreign direct investment across China. Journal of International Money and Finance, 21, 79-113. http://dx.doi.org/10.1016/S0261-5606(01)00032-8

Wang, Z. Q., \& Swain, N. J. (1995). The determinants of foreign direct investment in transforming economies: Evidence from Hungary and China. Review of World Economics, 131, 359-82. http://dx.doi.org/10.1007/BF02707440

Wei, Y., \& Liu, X. (2001). Foreign direct investment in China: Determinants and impact. Edward Elgar. Northampton.

Wei, Y., Liu, X., Parker, D., \& Vaidya. K. (1999). The regional distribution of foreign direct investment in China. Regional Studies, 33(9), 857-867. http://dx.doi.org/10.1080/00343409950075498

Wheeler, D., \& Mody, A. (1992). International investment location decisions: the case of US Firms. Journal of International Economics, 33, 57-76. http://dx.doi.org/10.1016/0022-1996(92)90050-T

Wu, C. (1991). A survey of FDI in mainland China. Beijing: Zhongguo Caizheng Jingji Press.

$\mathrm{Wu}, \mathrm{X}$., \& Strange, R. (2000). The location of foreign insurance companies in China. International Business Review, 9, 383-398. http://dx.doi.org/10.1016/S0969-5931(00)00007-X

Xing, Y., \& Wan, G. (2006). Exchange rates and competition for FDI in Asia. World Economics, $29,419$. http://dx.doi.org/10.1111/j.1467-9701.2006.00791.x

$\mathrm{Xu}, \mathrm{K}$. (1992). Analysis of the industrial structure of industrial investment by foreigners and its policies selection. China Industrial Economic Research, 7, 38-44.

Zhang, L. (1994). Location-specific advantages and manufacturing direct foreign investment in south China. World Development, 22(1), 43-53. http://dx.doi.org/10.1016/0305-750X(94)90167-8

Zhao, H., \& Zhu, G. (1998). Determinants of ownership preference of international joint ventures: New evidence from Chinese manufacturing industries. International Business Review, 7, 569-89. http://dx.doi.org/10.1016/S0969-5931(98)00032-8

Zhao, H., \& Zhu, G. (2000). Location factors and country-of origin differences: An empirical analysis of FDI in China. Multinational Business Review, 8(1), 60.

Zhou, C., Delios, A., \& Yang, J. (2002). Locational determinants of Japanese foreign direct investment in China. Asia Pacific Journal of Management, 19(1), 63-86. http://dx.doi.org/10.1023/A:1014839607180

Appendix 1. Definition of independent variables

\begin{tabular}{ll}
\hline Variables & Sub-items \\
\hline \multirow{3}{*}{ Country of origin } & Nominal variable: \\
& -coded 1 if country of origin is European, 2 if USA, 3 if Japan, 4 if Hong Kong and South Asia, 5 for other \\
& countries \\
& Nominal variable: \\
& -coded 1 if the activity sector is Aeronautics \& Maritime, 2 if automotive, 3 if consumer goods, 4 if industrial \\
Activity sector & products, 5 if materials, 6 if paper, packaging \& printing, 7 if textiles and 8 if general manufacturing \\
& Dichotomous variable: \\
Multi-branches & -coded 1 if country of origin is European, 2 if USA, 3 if Japan, 4 if Hong Kong and South Asia, 5 for other \\
& countries \\
Wage level & Nominal variable: \\
Land price & -coded 1 if worker average annual wage is less than 15K, 2 if between 15K and 30K and 3 otherwise \\
\hline
\end{tabular}


-coded 1 if land price is has in average increased less than 10\% between 2003 and 2005, 2 if the increase is between $10 \%$ and $20 \%$ and 3 if the increase is more than $20 \%$

Ratio funds allocated to the region divided by population

Educational funds Dichotomous variable:

-coded 1 if lower than 1, 2 otherwise

High education Ratio Enrollment rate in the region divided by total enrollment

enrollment Nominal variable:

-coded 1 if ratio value is less than 2.25, 2 if between 2.25 and 4.5 and 3 if higher than 4.5

Gross regional product

Nominal variable:

-coded 1 if GRP is less than $17.5 \mathrm{~K}, 2$ if between $17.5 \mathrm{~K}$ and $35 \mathrm{~K}$ and 3 if more than $35 \mathrm{~K}$ (unit: 100 million Yuan)

Freight activity in ton-kilometers (railways, highways, waterways)

Infrastructure Quality

Nominal variable:

-coded 1 if freight activity is lower than 4 million ton-km, 2 if between 4 and 8 ton-km and 3 otherwise

Localization

Nominal variable:

(Metropolitan/not)

-coded 1 if city population is less than 1 million, 2 if population is between 1 and 2 million and 3 otherwise

Ratio number of patents granted divided by number of applications

Intellectual property

Dichotomous variable:

- coded 1 if ratio value is lower than national average (44.6\%), 2 otherwise.

\section{Copyrights}

Copyright for this article is retained by the author(s), with first publication rights granted to the journal.

This is an open-access article distributed under the terms and conditions of the Creative Commons Attribution license (http://creativecommons.org/licenses/by/3.0/). 